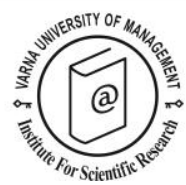

\title{
European tourism indicator system for sustainable destination management in county Donegal, Ireland
}

\author{
Emmet McLoughlin ${ }^{1 *}$, James Hanrahan ${ }^{2}$, Ann Marie Duddy ${ }^{3}$ and Séan Duffy ${ }^{4}$
}

Received: 17/01/2018 Accepted: 25/05/2018

1 Department of Marketing, Tourism and Sport, Institute of Technology, Sligo, Ireland. Email: Emmet.mcloughlin@mail.itsligo.ie

${ }^{2}$ Department of Marketing, Tourism and Sport, Institute of Technology, Sligo, Ireland

${ }^{3}$ Department of Environmental Science, Institute of Technology, Sligo, Ireland

${ }^{4} \mathrm{Head}$ of School of Tourism, Letterkenny Institute of Technology, Donegal, Ireland

* Corresponding author

\begin{abstract}
Tourism is one of Ireland's most important economic sectors. In 2017, the overall visits to the country have increased by over $10 \%$. However, such growth if not managed correctly can present many challenges to destinations, particularly along Irelands $2500 \mathrm{~km}$ driving route, the Wild Atlantic Way (WAW). This paper reports on the application of the European Tourism Indicator System for sustainable destination management in County Donegal, Ireland. While significant data was generated on tourism activity at local level, results do suggest that a number of the indicators would need further research going forward. This evidence informed approach to tourism planning can assist Local Authorities in future planning considerations, while also helping to protect the long-term sustainability of the tourism product in County Donegal.
\end{abstract}

(C) 2018 Varna University of Management. All rights reserved

Keywords: Wild Atlantic Way (WAW); Tourism indicators; Evidence informed planning; European Tourism Indicators System; Ireland

Citation: McLoughlin, E., J. Hanrahan, A. Duddy, S. Duffy (2018) European tourism indicator system for sustainable destination management in county Donegal, Ireland. European Journal of Tourism Research 20, pp. 78-91

\section{Introduction}

Ireland is currently experiencing a boom in its tourism industry. According to Fáilte Ireland (2017), there were 7.7 million overseas visitors coming to Ireland during the months of January to September alone, an increase of $2.9 \%$ on 2016. Delivering a sustainable tourism sector can maximise tourism's economic and social contribution. While, the connection between tourism, sustainability and planning has never been closer (UNWTO, 2004) and it continues to garner increased attention within academic circles (Dredge and Jenkins, 2011). We must first acknowledge the challenges posed by the emerging strong patterns of growth in the tourism sector and take a pre-emptive 
approach to addressing them. For example, the exact impact of Brexit on Ireland's tourism industry has yet to unfold in its entirety. As noted by McLoughlin and Hanrahan (2017), uncertainty looms over whether travellers from the Northern Ireland will once again face border checks and if visitors from Britain will be restricted from free movement in the EU. Such issues could have a major impact on one such destination, located in the periphery of North West Ireland, County Donegal due to its close proximity to the border with Northern Ireland. Therefore, an evidence informed approach to planning for tourism, from data collected through tourism indicators can be an ideal approach to ensure the future long-term sustainability of the tourism industry in County Donegal.

Mowforth and Munt (2016) identify tourism indicator systems as one of their tools of sustainability that can be utilised in the tourism planning process. Indicators have often been regarded as significant tools when it comes to to planning for rural and cultural tourism (Blancas et al., 2011; Lozano-Oyola et al., 2012; Lee and Hsieh, 2016) and managing community tourism (Choi and Sirakaya, 2006). And through the application of the European Tourism Indicator System (ETIS) for sustainable destination management, Local Authorities can develop appropriate policy based on evidence when planning for tourism at local level. However, despite their importance in assessing destinations (Pérez et al, 2013) and in measuring responsible behaviour (Blackstock et al, 2008), their application in Ireland continues to be overlooked (McLoughlin, 2017). For example, over $€ 317,000$ was provided for the development of the DIT ACHIEV Model to help the impacts of tourism (Griffin, Morrissey and Flanagan, 2010). Yet despite its endorsement by Fáilte Ireland (NTDA), this comprehensive indicator system remains unused in Ireland. This has resulted in data collection on tourism activity, specific to each county and the monitoring of the sustainability of destinations around Ireland at local level being neglected. To address this research gap, the Wild Atlantic Way Research Group (WAWRG) coordinated the application of the ETIS in County Donegal, and this paper presents baseline data on a number of the indicators. Thus, contributing to new knowledge on evidence informed planning for tourism in Ireland through a recognised indicator system.

\section{Literature Review}

The UNWTO has designated 2017 as the year of sustainable tourism for development (UNWTO, 2015). This shows a willingness on behalf of the UNWTO to encourage destinations to develop tourism in a way that takes full account of its current and future economic, social and environmental impacts, while also addressing the needs of visitors, the industry, the environment and host communities (UNEP and UNWTO, 2005). Rio and Nunes (2012) state that to guarantee its long-term sustainability, there is a need for continued monitoring and evaluation of tourism's impacts at destination level. Yet the complexity of sustainability in tourism makes it difficult to develop a method for measuring it (McLoughlin, 2017). Torres-Delgado and Palomeque (2014) note how there is no consensus on how to construct and apply such a method. Blancas et al (2015) does make it clear however, that to promote a sustainable form of tourism and stimulate the competitiveness of the tourism sector, it is necessary to have a system of sustainable tourism indicators.

The use of tourism indicators continues to be advocated and discussed over the years (Griffin, Morrissey and Flanagan, 2010; TorresDelgado and Palomeque, 2014; McLoughlin, 2017). According to Miller and Twinning-Ward (2012), they help in identifying sustainable management strategies. Such a task is of vital importance if tourism considering the sustainable development of tourism should promote the optimal use of resources (UNWTO, 2004). Tourism indicator systems have the ability to quantify, assess, monitor measure and communicate relevant information (Roberts and Tribe, 2008). According to the WTO (1996) and later Mowforth and Munt (2016) they provide the necessary information to better understand the links between the impact of tourism on the cultural and natural setting in which this take place and on which it is strongly dependent. Besides tourism, indicator systems are flexible 
to existing management structures (Conaghan, 2013; McLoughlin, 2017), even the legally required process for Local Authorities in Ireland to develop their County Development Plan (CDP). Local Authorities can develop future tourism policy on evidence through data collected by tourism indicator systems, thus facilitating an evidence informed approach to tourism planning locally. Moreover, with the increasing number of visitors to Ireland and the popularity of key tourism products such as Sliabh Liag cliffs and Malin Head in County Donegal, evidence in tourism planning is now therefore essential. This is where the ETIS can play a significant role in facilitating such an approach to future planning.

Needham and Szuster (2011) note how tourism can affect the environment. For decades, discussions on the impact of tourism on the natural environment has been at the centre of several theoretical discussions (Amuquandoh, 2010; Buckley, 2011; Davenport and Davenport, 2006; Geneletti and Dawa, 2009; Griscom and Ashton, 2011; Hiltunen, 2007; Holden, 2008; Li, Yang, Liu, and Zheng, 2014; Hanrahan and McLoughlin, 2016). Greenhouse gas emissions associated with travel, accommodations, and recreational activities continue to be highlighted by NGOs and governmental departments (Gössling and Schumacher, 2010; Lee and Hsieh, 2016). The indicators of the ETIS require the collection of data on reducing the impact of transport, climate change, waste and water management, energy usage and biodiversity protection. By collecting such data, Local Authorities can be in a position to establish many of the root causes of negative environmental impacts from tourism and protect Ireland's clean green image abroad. Thus, enabling local communities to benefit economically from visitor arrivals.

Taking the symbolic relationship between tourism and foreign exchange earnings, generation of income, employment and regional and local development (Mason, 2016). Cooper et al (2008) discusses the economic impact of tourism activities is often estimated based on data on number of arrivals, receipt per tourist, average length of stay and other economic indicators. These indicators are all contained within the ETIS. Therefore, collecting data on the economic indicators of the ETIS can allow Local Authorities to track the contribution of tourism to economic sustainability in their county while focusing on supporting local tourism enterprises thorough sharing data on visitor spending patterns.

Tourist destination are building their competitiveness by leveraging their cultural heritage (Sasaki, 2004; Alberti and Giusti, 2012). Ireland's rich history of culture is a significant draw for tourists, with three out of five $(64 \%)$ of overseas holidaymaker's point to Ireland's history and culture as a crucially important factor in their choice to come here, with three quarters (74\%) registering a high satisfaction rate with what they find here (Fáilte Ireland, 2013). Through the application of the ETIS, Local Authorities can benefit from data on the relationship between tourism and social and cultural sustainability at local level that can be benchmarked year on year. The social cultural indicators of the ETIS can also provide valuable information relating to community and social impacts of tourism, which could be of significant importance to local communities now with the rising visitor numbers to Ireland. Furthermore, through the application of the ETIS, Local Authorities could also monitor changes in health and safety of visitors, gender equality in tourism enterprises together with inclusion and accessibility going forward.

While gathering gather data on tourism activity is importance for its future sustainability, how the destination is managed can have an important impact on its future direction. It is essential that destinations adapt their approach to tourism planning in order to ensure the longterm sustainability of the industry. Data on sustainable management in tourism enterprises and customer satisfaction can aid Local Authorities in addressing many of tourism negative impacts locally, while protecting the quality of the visitor experience.

Head (2008) notes how evidence has become central to the design, implementation and evaluation of policies and programmes. Without collecting data on tourist activity, Local Authorities would be unable to get ahead of challenges that tourism in their county may face in the future. The aim of the ETIS is to 
improve the sustainable management of destinations through benchmarking (EC, 2016) by providing a free and straightforward to implement tool-kit. Its application in County Donegal, can enable Local Authorities to share and benchmark their progress and performance for the future.

\section{Materials and Methods}

This study focuses on the application of the ETIS in County Donegal, Ireland. Donegal is located in Irelands North West region and shares a land border with Northern Ireland to the east and the Atlantic Ocean to the west. For the purposes of this study, the authors used the Local Authority county boundary as the destination parameter. This was due to the legal remit of the Local Authority in planning for infrastructure.

Both the ETIS website and toolkit contain a number of tools to collect and collate information on tourist destinations. This includes pre-developed surveys for visitors, residents and enterprises, together with the destination profile and data sheet. The aims of this study was to gather the necessary data on the 43 indicators of the ETIS in County Donegal. This includes the 21 core indicators and the 22 optional indicators. The indicators are divided into a number of categories (Destination Management, Economic Value, Social and Cultural Impact and Environmental Impact). The study sought to obtain data on all 42 indicators.

Preliminary research was desk-based and the authors investigated the availability of information held by organisations (CSO, Fáilte Ireland, etc.) on the various indicators. In some instances, data was not directly available in literature for a specific indicator but involved calculations based on available data. This was facilitated through the formulas provided by the ETIS for the calculation of data for a variety of indicators (these are all contained within the ETIS Data Sheet http://ec.europa.eu/Docs Room/documents/15849). As noted by Denscombe (2003), surveys are a popular method for investigating attitudes and actions. The authors then complimented preliminary research with the utilisation of the three pre- existing surveys (resident, visitor and enterprise) that accompany the ETIS tool-kit.

Sampling is one of the most fundamental elements of research (Sarantakos, 2005). For this study the authors followed a stratified random sampling procedure when carrying out the resident, visitor and enterprise surveys in County Donegal. Besides, authors have employed similar approaches in previous studies to gain insights into the perceptions of tourism development. For example, Pulina, Meleddu and Del Chiappa (2016) employed stratified random sampling to identify the factors that influence resident's choice of a particular type of tourism in Italy. While Xu et al (2016) also used this procedure to study residents' perceptions of wine tourism development in terms of personal benefits and community impacts in the United States.

By employing a 95\% confidence level with an $8 \%$, standard deviation, the authors carried out the resident and visitor surveys in 'honey pot' destinations along the WAW in County Donegal over the months of August and early September 2017, this resulted in a sample of 157 visitors, 157 residents and 115 tourism enterprises (see Table 1). The decision to carry out the data collection at these locations was due the high footfall and the facilitation of expeditious and efficient collection of data on tourism activity.

All visitor and resident's surveys were completed face to face, and all questions were read out in full and explained were necessary. Regarding tourism enterprises, the stratification included different businesses such as accommodation, catering, entertainment, and outdoor recreation and transport providers to encompass a suitable cross section of enterprises. The authors found the most suitable option was to conduct the surveys over the phone, with a number being conducted face to face were possible.

The authors did find that many of the questions contained within the visitor survey were not required for the indicator data sheet, with some being ambiguous. Regardless, the response rate for all three surveys was exactly the recommended sample size. All the elements 
Table 1.Demographic Breakdown of Sample

\begin{tabular}{|c|c|c|}
\hline \multicolumn{3}{|l|}{ Demographic Breakdown of Sample } \\
\hline \multicolumn{3}{|l|}{ Visitors $(n=157) \%$ share $n$} \\
\hline Male & $50 \%$ & $\mathrm{n}=78$ \\
\hline Female & $50 \%$ & $\mathrm{n}=79$ \\
\hline \multicolumn{3}{|l|}{ Age } \\
\hline$>25$ & $25 \%$ & $\mathrm{n}=39$ \\
\hline $25-34$ & $25 \%$ & $\mathrm{n}=39$ \\
\hline $35-44$ & $25 \%$ & $\mathrm{n}=40$ \\
\hline $45+$ & $25 \%$ & $\mathrm{n}=39$ \\
\hline \multicolumn{3}{|l|}{ Country of origin } \\
\hline United Kingdom (Britain and Northern Ireland) & $25 \%$ & $\mathrm{n}=39$ \\
\hline $\begin{array}{l}\text { Mainland Europe (France, Germany, Italy, Spain, Netherlands, Belgium, Denmark, } \\
\text { Sweden, Switzerland, Austria, Norway, Poland and other) }\end{array}$ & $25 \%$ & $\mathrm{n}=40$ \\
\hline North America (USA and Canada) & $25 \%$ & $\mathrm{n}=39$ \\
\hline Rest of the World (Australia, New Zealand, Other Oceania and Other areas) & $25 \%$ & $\mathrm{n}=39$ \\
\hline \multicolumn{3}{|l|}{ Residents $(n=157) \%$ share $n$} \\
\hline Bundoran & $25 \%$ & $\mathrm{n}=40$ \\
\hline Ardara & $25 \%$ & $n=39$ \\
\hline Donegal Town & $25 \%$ & $\mathrm{n}=39$ \\
\hline Dungloe & $25 \%$ & $\mathrm{n}=39$ \\
\hline \multicolumn{3}{|l|}{ Tourism Enterprises $(n=115) \%$ share $n$} \\
\hline Accommodation & $17 \%$ & $\mathrm{n}=20$ \\
\hline Catering & $17 \%$ & $\mathrm{n}=20$ \\
\hline Entertainment Provider & $16 \%$ & $\mathrm{n}=18$ \\
\hline Outdoor Recreation Provider & $17 \%$ & $\mathrm{n}=19$ \\
\hline Transport & $16 \%$ & $\mathrm{n}=18$ \\
\hline Other & $17 \%$ & $n=20$ \\
\hline
\end{tabular}

collected from each of the three surveys were recorded into numerical variables using analytical software (SPSS). All data was then manually inputted into the ETIS datasheet for County Donegal, discussion of the results and the drawing of conclusions and recommenddations followed this.

\section{Results and Discussion}

Irish flora and fauna and their associated habits are an important product of Ireland's tourism industry (McLoughlin and Hanrahan, 2016), therefore the environmental impacts of tourism need to be managed through data collection of tourist activity. The visitor's survey in County Donegal revealed that the average distance travelled by tourists from home to the destination was $1815 \mathrm{~km}$. Furthermore, $65 \%$ of tourists and same day visitors used different modes of transport to arrive at their destination. Considering the many tourist activities, it is transportation that produces the most greenhouse emissions. Yet the percentage of tourists and same day visitors using environmentally friendly and or public transport was $15 \%$. This is worrying as tourists can actively reduce their emissions by choosing sustainable modes of transport (Juvan and Dolnicar, 2017). It should be noted however, that County Donegal does not have access to Ireland's rail network. The average carbon footprint of tourists and same day visitors travelling from home to County Donegal was found to be $158 \mathrm{~kg} \mathrm{CO} 2$ per person. This figure was analysed using the EPA recommended calculator (Carbon Footprint Ltd) and is based on a one-way trip. However, if you take domestic visitors out of the calculation, the average footprint rises to $275 \mathrm{~kg} \mathrm{CO} 2$. This highlights the impact of airline travel to the destination.

The enterprise surveys revealed that a significant number of tourism accommodations and attractions (72\%) were found to be in "vulnerable zones". It must be noted that this research was carried out during a period of extreme weather in the northern region of County Donegal costing an estimated $€ 15.3 \mathrm{~m}$ to repair road damage alone with costs for other infrastructural damage including housing, community, and amenity facilities still being 
calculated (Irish Examiner 11/09/2017). Furthermore, there was a low uptake of climate mitigation schemes by tourism enterprises $(1 \%)$. It is important however to recognise the integrity of the tourism enterprises here and to note while it's easy to state your participating in climate mitigating schemes, the enterprises who participated in this study appear to be genuine and seem to be avoiding any potential move towards greenwashing.

There was little information available in literature on waste generation by tourists in County Donegal, and indeed nationally, and its subsequent management. Neither the

Table 2. Environmental impact indicators

\begin{tabular}{|c|c|c|c|c|}
\hline Criteria & $\begin{array}{l}\text { Indicator } \\
\text { Ref }\end{array}$ & Indicator & $\begin{array}{l}\text { Suggested } \\
\text { Target }\end{array}$ & $\begin{array}{l}\text { Destination } \\
\text { Result }\end{array}$ \\
\hline \multirow{4}{*}{$\begin{array}{l}\text { D.1 Reducing } \\
\text { Transport } \\
\text { Impact }\end{array}$} & D.1.1 & $\begin{array}{l}\text { Percentage of tourists and same day visitors using } \\
\text { different modes of transport to arrive at the destination }\end{array}$ & $\begin{array}{l}\text { No EC } \\
\text { Target }\end{array}$ & $65 \%$ \\
\hline & D.1.2 & $\begin{array}{l}\text { Percentage of tourists and same day visitors using } \\
\text { local/soft mobility/public transport services to get } \\
\text { around the destination }\end{array}$ & $15.1 \%$ & $15 \%$ \\
\hline & D.1.3 & $\begin{array}{l}\text { Average travel }(\mathrm{km}) \text { by tourists and same day visitors } \\
\text { from home to the destination }\end{array}$ & $\begin{array}{l}\text { No EC } \\
\text { Target }\end{array}$ & $1815 \mathrm{~km}$ \\
\hline & D.1.4 & $\begin{array}{l}\text { Average carbon footprint of tourists and same day } \\
\text { visitors travelling from home to the destination= TV } \\
\text { (For International only see IV. The ETIS requests one } \\
\text { way, for a round trip the figures need to be doubled). }\end{array}$ & $\begin{array}{l}\text { No EC } \\
\text { Target }\end{array}$ & $\begin{array}{l}\mathrm{TV}=158 \mathrm{~kg} \\
\mathrm{CO} 2 \\
\mathrm{IV}=275 \mathrm{~kg} \\
\mathrm{CO} 2\end{array}$ \\
\hline \multirow[t]{2}{*}{$\begin{array}{l}\text { D.2 Climate } \\
\text { Change }\end{array}$} & D.2.1 & $\begin{array}{l}\text { Percentage of tourism enterprises involved in climate } \\
\text { change mitigation schemes-such as: } \mathrm{CO}_{2} \text { offset, low } \\
\text { energy systems, and "adaptation" responses and } \\
\text { actions }\end{array}$ & $\begin{array}{l}\text { No EC } \\
\text { Target }\end{array}$ & $1 \%$ \\
\hline & D.2.2 & $\begin{array}{l}\text { Percentage of tourism accommodation and attraction } \\
\text { infrastructure located in "vulnerable zones" }\end{array}$ & $\begin{array}{l}\text { No EC } \\
\text { Target }\end{array}$ & $72 \%$ \\
\hline \multirow{3}{*}{$\begin{array}{l}\text { D.3 Solid } \\
\text { Waste } \\
\text { Management }\end{array}$} & D.3.1 & $\begin{array}{l}\text { Waste production per tourist night compared to gene- } \\
\text { ral population waste production per person (kilos) }\end{array}$ & $\begin{array}{l}\text { No EC } \\
\text { Target }\end{array}$ & $\begin{array}{l}\mathrm{R}=0.37 \mathrm{~kg} \\
\mathrm{~T}=0.74 \mathrm{~kg}\end{array}$ \\
\hline & D.3.2 & $\begin{array}{l}\text { Percentage of tourism enterprises separating different } \\
\text { types of waste }\end{array}$ & $\begin{array}{l}\text { No EC } \\
\text { Target }\end{array}$ & $73 \%$ \\
\hline & D.3.3 & $\begin{array}{l}\text { Percentage of total waste recycled per tourist compa- } \\
\text { red to total waste recycled per resident per year }\end{array}$ & $23 \%$ & $R=52 \%$ \\
\hline $\begin{array}{l}\text { D.4 Sewage } \\
\text { Treatment }\end{array}$ & D.4.1 & $\begin{array}{l}\text { Percentage of sewage from the destination treated at } \\
\text { least at secondary level prior to discharge }\end{array}$ & $\begin{array}{l}\text { No EC } \\
\text { Target }\end{array}$ & $72 \%$ \\
\hline \multirow{3}{*}{$\begin{array}{l}\text { D. } 5 \text { Water } \\
\text { Management }\end{array}$} & D.5.1 & $\begin{array}{l}\text { Water consumption per tourist night compared to } \\
\text { general population water consumption per resident } \\
\text { night }\end{array}$ & $\begin{array}{l}\text { No EC } \\
\text { Target }\end{array}$ & $150(N)$ \\
\hline & D.5.2 & $\begin{array}{l}\text { Percentage of tourism enterprises taking actions to } \\
\text { reduce water consumption }\end{array}$ & $\begin{array}{l}\text { No EC } \\
\text { Target }\end{array}$ & $16 \%$ \\
\hline & D.5.3 & $\begin{array}{l}\text { Percentage of tourism enterprises using recycled } \\
\text { water }\end{array}$ & $\begin{array}{l}\text { No EC } \\
\text { Target }\end{array}$ & $16 \%$ \\
\hline \multirow{3}{*}{$\begin{array}{l}\text { D.6 Energy } \\
\text { Usage }\end{array}$} & D.6.1 & $\begin{array}{l}\text { Energy consumption per tourist night compared to } \\
\text { general population energy consumption per resident } \\
\text { night }\end{array}$ & $\begin{array}{l}\text { No EC } \\
\text { Target }\end{array}$ & $\begin{array}{l}\mathrm{R}=49.68 \mathrm{MJ} \\
\mathrm{T}=226 \mathrm{MJ}\end{array}$ \\
\hline & D.6.2 & $\begin{array}{l}\text { Percentage of tourism enterprises that take actions to } \\
\text { reduce energy consumption }\end{array}$ & $\begin{array}{l}\text { No EC } \\
\text { Target }\end{array}$ & $18 \%$ \\
\hline & D.6.3 & $\begin{array}{l}\text { Percentage of annual amount of energy consumed } \\
\text { from renewable sources (Mwh) compared to overall } \\
\text { energy consumption at destination level per year }\end{array}$ & $\begin{array}{l}\text { No EC } \\
\text { Target }\end{array}$ & $9.1 \%(\mathrm{~N})$ \\
\hline $\begin{array}{l}\text { D.7 } \\
\text { Landscape } \\
\text { and } \\
\text { Biodiversity } \\
\text { Management }\end{array}$ & D.7.1 & $\begin{array}{l}\text { Percentage of local enterprises in the tourism sector } \\
\text { actively supporting protection, conservation, and } \\
\text { management of local biodiversity and landscapes. }\end{array}$ & $9 \%$ & $17 \%$ \\
\hline
\end{tabular}


enterprise survey nor the visitor's survey included questions on the volume of waste generated by tourists. Data was available from the Connaught Ulster Waste Management Plan on the amount of waste produced by residents in County Donegal and this was reported to be $135 \mathrm{~kg}$ per year (Connaught Ulster Waste Region, 2015), which was calculated to be 0.37 $\mathrm{kg}$ per day. It is reported that tourists produce twice the volume of waste, when compared to the general population (EC, 2013) and therefore a value of $0.74 \mathrm{~kg}$ per tourist per day may be estimated for waste generated by tourists although this value requires verification by further research.

The enterprise surveys revealed that $73 \%$ of tourism enterprises segregated waste. While $95 \%$ of organic waste is separated and diverted from landfill, and, where possible, sent for anaerobic digestion or alternative energy recovery (EC, 2013). The ETIS survey does not require information on the level of segregation i.e. dry recyclables vs. organic waste.

The recycling rate reported for municipal waste in the Connaught Ulster Region is reported to be $59 \%$ (Connaught Ulster Waste Region, 2015). The EC JRC Report on Best Environmental Management Practice in the Tourism Sector apply a benchmark of $84 \%$ of waste to be recycled, expressed on a weight basis and require that less than $0.16 \mathrm{~kg}$ of waste per guest night ends of up in landfill (EC, 2013). A further benchmark of recycling of greater than $95 \%$ of organic waste is set. Such segregation measures can help reduce the volume of waste going to landfills while also encouraging recycling (EC, 2013). However, information was currently unavailable on the percentage of waste recycled per tourist and this area requires further investigation.

For tourism destinations, the treatment of sewage is fundamental to their sustainability. In county Donegal, approximately $72 \%$ of sewage is treated to at least at secondary level prior to discharge to waterbodies. This value was calculated from EPA data obtained for the various wastewater treatment plants in County Donegal and relating to the population equivalent served by each plant and the treatment level achieved by each agglomeration (EPA, 2016) prior to discharge. While wastewater treatment has improved dramatically in Co. Donegal with new wastewater treatment plants having come into operation in recent years, a number of locations continue to discharge raw/partially treated sewage to waterbodies. Many wastewater treatment plants in Co. Donegal are undersized i.e. the plant was not originally designed to treat the volume of wastewater currently being received. The under capacity of these wastewater treatment plants is not taken into account in the aforementioned $72 \%$ removal rate.

While information was unavailable on water consumption by tourists in Donegal or indeed nationally, according to Gössling et al, (2012) tourists in Ireland consume approximately 150 litres of water per night. Furthermore, the enterprise surveys reveal that $16 \%$ of tourism enterprises in county Donegal are taking actions to reduce water consumption with another $16 \%$ found to be using recycled water. Without the necessary systems in place to conserve and recycle water at popular destinations in Donegal, the increasing numbers of visitors could put pressure on local water services, which are already under serious pressure from a lack of investment over the years (Paul Melia, Irish Independent, 20/05/2018).

Residents in Ireland consume $49.68 \mathrm{MJ}$ of energy per day (https://www.worlddata.info/ europe/ireland/energy-consumption.php).

According to the UNWTO (2017), the average hotel energy consumption per guest night in Europe was $226 \mathrm{MJ}$. Data was not available on energy consumption per tourist night in Co. Donegal or indeed nationally. Therefore, this one area does require further research. It was found that $18 \%$ of tourism enterprises in Donegal had measures in place to reduce their energy consumption such as energy saving light bulbs. The EC JRC report on Best Environmental Management Practice in the Tourism Sector apply a benchmark of $50 \%$ of energy supply in tourist accommodation to be generated by on-site renewable sources or by verifiable off-site renewable energy sources (EC, 2013). However, no information was available at local level on the annual amount 
renewable energy consumed in Donegal. At national level, renewable energy contributed to $9.1 \%$ of total energy consumption (SEAI, 2016). Increased investment by tourism enterprise in energy reduction initiatives can save money while reducing the tourism energy footprint.

The continued growth in visitor arrivals necessitates the economic impacts of tourism to be monitored and managed. County Donegal was found to receive a significant number of both overnight and same day visitors per month. These arrivals can make a significant contribution to the economy and the relative contribution of tourism to Irelands GNP reflects this. However, the irregular nature of tourism arrivals can affect the provision of seasonal employment among tourism enterprises. From the enterprise surveys, it was found that $26 \%$ of jobs in the tourism sector in County Donegal were seasonal, a figure well short of the suggested average noted by the EC (EC, 2016). This shows that County Donegal with its wide quantity and variety of tourist and paratourist activities is not heavily exposed to seasonal variations.
In terms of spending patterns of tourists and same day visitors to County Donegal, the visitor surveys have shown that overnight visitors to County Donegal spend on average $€ 104.16$ per tourist. In comparison to same day visitors, again there was a substantial level of tourist expenditure with an average daily spend being $€ 55.80$ per same day visitor. Taken together with the average length of stay, these figures illustrate that County Donegal is receiving a significant yield from the presence of overnight and same day visitors. The occupancy rate across all commercial accommodation in County Donegal was found to be $41 \%$ (Fáilte Ireland, 2016). This figure was however, below the suggested target of $64 \%$ discussed by the EC (EC, 2016). It is the economic benefits from tourism development are one of the more prevalent reasons for destinations to seek out tourism as a development tool (Nickerson, Jorgenson and Boley, 2016). Findings from the application of the economic indicators of the ETIS point to tourism playing a significant role in job creation and the use of local goods and services in County Donegal, this needs to be nourished and protected going forward.

Table 3. Economic value indicators

\begin{tabular}{|c|c|c|c|c|}
\hline Criteria & $\begin{array}{l}\text { Indicator } \\
\text { Ref }\end{array}$ & Indicator & $\begin{array}{l}\text { Suggested } \\
\text { Target }\end{array}$ & $\begin{array}{l}\text { Destination } \\
\text { Result }\end{array}$ \\
\hline \multirow{5}{*}{$\begin{array}{l}\text { B. } 1 \text { Tourism } \\
\text { Flow (volume } \\
\text { and value) at } \\
\text { the Destination }\end{array}$} & B.1.1 & Number of tourist nights per month & $\begin{array}{l}\text { No EC } \\
\text { Target }\end{array}$ & 234,332 \\
\hline & B.1.2 & Number of same day visitors per month & $\begin{array}{l}\text { No EC } \\
\text { Target }\end{array}$ & 30,833 \\
\hline & B.1.3 & $\begin{array}{l}\text { Relative contribution of tourism to the destination's } \\
\text { economy (\% GDP) }\end{array}$ & $\begin{array}{l}\text { No EC } \\
\text { Target }\end{array}$ & $\begin{array}{l}4.4 \%(\mathrm{~N}- \\
\text { GNPI) }\end{array}$ \\
\hline & B.1.4 & Daily spending per overnight tourist & $€ 64$ & $€ 104.16$ \\
\hline & B.1.5 & Daily spending per same day visitor & $€ 42.84$ & $€ 55.80$ \\
\hline \multirow{2}{*}{$\begin{array}{l}\text { B.2 Tourism } \\
\text { Enterprise(s) } \\
\text { Performance }\end{array}$} & B.2.1 & Average length of stay of tourists (nights) & 5.4 & $\begin{array}{l}4.7 \\
\text { (overseas) } \\
4.0 \\
\text { (domestic) }\end{array}$ \\
\hline & B.2.2 & $\begin{array}{l}\text { Occupancy rate in commercial accommodation } \\
\text { establishments per month and average for the } \\
\text { year (please not this figure covers all } \\
\text { accommodation types) }\end{array}$ & $64 \%$ & $41 \%$ \\
\hline \multirow{2}{*}{$\begin{array}{l}\text { B.3 Quantity } \\
\text { and Quality of } \\
\text { Employment }\end{array}$} & B.3.1 & $\begin{array}{l}\text { Direct tourism employment as percentage of total } \\
\text { employment in the destination }\end{array}$ & $3.3 \%$ & $8 \%$ \\
\hline & B.3.2 & Percentage of jobs in tourism that are seasonal & $24 \%$ & $26 \%$ \\
\hline $\begin{array}{l}\text { B. } 4 \text { Tourism } \\
\text { Supply Chain }\end{array}$ & B.4.1 & $\begin{array}{l}\text { Percentage of locally produced food, drink, goods } \\
\text { and services sourced by the destinations tourism } \\
\text { enterprises }\end{array}$ & $\begin{array}{l}\text { No EC } \\
\text { Target }\end{array}$ & $39 \%$ \\
\hline
\end{tabular}


European tourism indicator system for sustainable destination management in county Donegal, Ireland.

Table 4. Social and cultural indicators

\begin{tabular}{|c|c|c|c|c|}
\hline Criteria & $\begin{array}{l}\text { Indicator } \\
\text { Ref }\end{array}$ & Indicator & $\begin{array}{l}\text { Suggested } \\
\text { Target }\end{array}$ & $\begin{array}{l}\text { Destination } \\
\text { Result }\end{array}$ \\
\hline \multirow{4}{*}{$\begin{array}{l}\text { C. } 1 \\
\text { Community/Social } \\
\text { Impact }\end{array}$} & C.1.1 & Number of tourists per 100 residents & 446.3 & 380 \\
\hline & C. 1.2 & $\begin{array}{l}\text { Percentage of residents who are satisfied } \\
\text { with tourism in the destination (per } \\
\text { month/season) }\end{array}$ & $\begin{array}{l}\text { No EC } \\
\text { Target }\end{array}$ & $74 \%$ \\
\hline & C.1.3 & $\begin{array}{l}\text { Number of beds available in commercial } \\
\text { accommodation establishment per } 100 \\
\text { residents }\end{array}$ & 5.7 & 7.5 \\
\hline & C.1.4 & Number of second homes per 100 homes & $\begin{array}{l}\text { No EC } \\
\text { Target }\end{array}$ & 18.4 \\
\hline $\begin{array}{l}\text { C.2 Health and } \\
\text { Safety }\end{array}$ & C.2.1 & $\begin{array}{l}\text { Percentage of tourists who register a } \\
\text { complaint with the police }\end{array}$ & $\begin{array}{l}\text { No EC } \\
\text { Target }\end{array}$ & $0 \%$ \\
\hline \multirow[b]{2}{*}{ C.3 Gender Equality } & C.3.1 & $\begin{array}{l}\text { Percentage of men and women employed in } \\
\text { the tourism sector }\end{array}$ & $49 \% \mathrm{~F}$ & $55 \% \mathrm{~F}$ \\
\hline & C.3.2 & $\begin{array}{l}\text { Percentage of tourism enterprises where the } \\
\text { general manager position is held by a } \\
\text { woman }\end{array}$ & $22 \%$ & $37 \%$ \\
\hline \multirow{4}{*}{$\begin{array}{l}\text { C. } 4 \\
\text { Inclusion/Accessibility }\end{array}$} & C.4.1 & $\begin{array}{l}\text { Percentage of rooms in commercial } \\
\text { accommodation establishments accessible } \\
\text { for people with disabilities }\end{array}$ & $\begin{array}{l}\text { No EC } \\
\text { Target }\end{array}$ & $46 \%$ \\
\hline & C.4.2 & $\begin{array}{l}\text { Percentage of commercial accommodation } \\
\text { establishments participating in recognised } \\
\text { accessibility information schemes }\end{array}$ & $\begin{array}{l}\text { No EC } \\
\text { Target }\end{array}$ & $25 \%$ \\
\hline & C.4.3 & $\begin{array}{l}\text { Percentage of public transport that is } \\
\text { accessible to people with disabilities and } \\
\text { with specific access requirements }\end{array}$ & $\begin{array}{l}\text { No EC } \\
\text { Target }\end{array}$ & $70 \%(N)$ \\
\hline & C. 4.4 & $\begin{array}{l}\text { Percentage of tourist attractions that } \\
\text { participating in recognised accessibility } \\
\text { information schemes }\end{array}$ & $\begin{array}{l}\text { No EC } \\
\text { Target }\end{array}$ & $23 \%$ \\
\hline \multirow{2}{*}{$\begin{array}{l}\text { C.5 Protecting and } \\
\text { Enhancing Cultural } \\
\text { Heritage, Local } \\
\text { Identity and cultural } \\
\text { Assets }\end{array}$} & C.5.1 & $\begin{array}{l}\text { Percentage of residents that are satisfied } \\
\text { with the impacts of tourism on destination's } \\
\text { identity }\end{array}$ & $\begin{array}{l}\text { No EC } \\
\text { Target }\end{array}$ & $79 \%$ \\
\hline & C.5.2 & $\begin{array}{l}\text { Percentage of the destination's events that } \\
\text { are focused on traditional/local culture and } \\
\text { heritage }\end{array}$ & $\begin{array}{l}\text { No EC } \\
\text { Target }\end{array}$ & $48 \%$ \\
\hline
\end{tabular}

Tourism inevitably takes people to new places while broadening their perception and knowledge of different cultures and environments (Hanrahan and McLoughlin, 2015). Such an encounter can affect local residents support for tourism. Through the resident survey of the ETIS, it was found that $74 \%$ of locals were satisfied with tourism, with $79 \%$ of locals we satisfied with its impact on the county's identity. These indicators need be tracked longitudinally over a specific period to identify changes as visitor arrivals are predicted to rise over the coming years.

The density of tourists per 100 residents was found to be below the suggest target of the ETIS. However, the number of second homes in the county was found to be high (18.4). Furthermore, according to Liu and Pratt (2017), personal security is a major concern for tourists and most tourists will seek safe and secure destinations. Data published by the Irish Tourist Assistance Service (ITAS) (2016) shows that no tourists in County Donegal registered a complaint with the police. This is encouraging as fear and insecurity are major barriers to travel (Buckley and Klemm, 1993). From the enterprise survey, it was found that $55 \%$ of women were employed in the tourism sector in County Donegal. While women continue to encounter a host of barriers, which are often manifested in gendered vertical and horizontal segregation (Ramos, Rey-Maqueira and Tugores, 2002). 
Through the enterprise surveys, it was found that $37 \%$ of general manager positions within tourism enterprises in County Donegal were found to be occupied by females. Furthermore, a growing body of work has examined the processes required to incorporate disability related considerations within tourism policy, planning and development (Vila, Darcy and Gonzalez, 2015). The enterprise surveys found the percentage of rooms in commercial accommodation accessible to people with disabilities in County Donegal to be $46 \%$.

Regarding recognised accessible information schemes, $25 \%$ of accommodation establishments in County Donegal have such programmes in place, with $23 \%$ of tourist attractions in the county are participating in recognised accessibility information schemes. It needs to be noted, that some natural or cultural attractions are not suitable to be converted for accessibility. Destination specific data was not available regarding the accessibility of the public transport network in Co Donegal to people with disabilities. However, according to Tourism Ireland (2017) at national level, $70 \%$ of the public transport network is accessible to people with disabilities. This is another avenue for future research for successful destination management going forward.

From analysing the enterprise surveys, it was found that $40 \%$ of tourism enterprises in County Donegal had an independent verification of their sustainability practices. This recognition of sustainable practice through certification has been considered the most promising of voluntary approaches (Foh, 1999) as it is used to enhance the credibility of the sector and awareness (Honey, 2002; Bauckham, 2005; Bien, 2007). Furthermore, Taplin (2013) notes that for tourism to remain viable, any destination management must ensure that visitors are satisfied and this level of satisfaction exceeds that obtained at competing venues.

Through the visitor surveys, it was found that Donegal had a high percentage of tourist and same day visitor satisfaction levels. This is significant as the quality of the visitor experience affects the ability of the destination to generate economic benefits and in turn employment. With many destinations along the WAW competing, this indicator needs to be monitored regularly. Additionally, the successful management of the destination can be a major factor in determining repeat visitors. In County Donegal, the percentage of repeat/return visitors was found to be $36 \%$. Further research could be carried out in the future to establish motivation factors of these repeat visitors who can often be more economically beneficial to the destination.

\section{Conclusion}

Evidence informed planning for tourism is now considered the way forward to help ensure the future sustainability of the tourism product. However, the application of tourism indicator systems in Ireland has been extremely limited to date (McLoughlin, 2017). This study contributes to new knowledge regarding the application of the ETIS in a popular tourist destination along Irelands Wild Atlantic Way. Through its application this study has collected baseline data on the impact of tourism on the

Table 5. Destination management indicators

\begin{tabular}{|l|l|l|l|l|}
\hline Criteria & $\begin{array}{l}\text { Indicator } \\
\text { Ref }\end{array}$ & Indicator & $\begin{array}{l}\text { Suggested } \\
\text { Target }\end{array}$ & $\begin{array}{l}\text { Destination } \\
\text { Result }\end{array}$ \\
\hline $\begin{array}{l}\text { A.1 Sustainable } \\
\begin{array}{l}\text { Tourism } \\
\text { Management in } \\
\text { Tourism } \\
\text { Enterprises }\end{array}\end{array}$ & A.1.1 & $\begin{array}{l}\text { Percentage of tourism } \\
\text { enterprises/establishments in the destination } \\
\text { using a voluntary certification/labelling for } \\
\text { environmental/quality/sustainability and/or } \\
\text { Corporate Social Responsibility measures }\end{array}$ & $\begin{array}{l}\text { No EC } \\
\text { Target }\end{array}$ & $40 \%$ \\
\hline $\begin{array}{l}\text { A.2 Customer } \\
\text { Satisfaction }\end{array}$ & A.2.1 & $\begin{array}{l}\text { Percentage of tourists and same day visitors } \\
\text { that are satisfied with their overall experience in } \\
\text { the destination }\end{array}$ & $99 \%$ & $97 \%$ \\
\cline { 2 - 5 } & A.2.2 & $\begin{array}{l}\text { Percentage of repeat/return visitors (within 5 } \\
\text { years) }\end{array}$ & $\begin{array}{l}\text { No EC } \\
\text { Target }\end{array}$ & $36 \%$ \\
\hline
\end{tabular}


local economy, community and environment of County Donegal. With the rapid growth in visitor numbers to Ireland, sewage treatment in the County is not up to a standard and current national policy is not protecting the natural environment that is prised by visitors. Therefore, the authors suggest that it would be necessary to monitor changes in this indicator going forward to support future guidelines for waste treatment at local level.

While tourists and same day visitors were found to be spending above the European average, the occupancy rates in commercial accommodation remain low, despite strong satisfaction levels among arrivals. With the Local Authorities combined responsibility for economic development, protecting community attributes and the natural environment, and managing tourism destinations, the authors consider that this base of evidence is a fundamental first step towards future informed planning and sustainability for tourism at local level.

In monitoring the economic value, sociocultural and environmental impacts of tourism, local stakeholders can access the necessary data to develop future tourism policy and current tourism planning. While the outcomes of this study have provided new material, and understanding regarding tourism activity in County Donegal. This study is not without limitations and opportunities for future research. To strategically strengthen the tourism opportunity locally in Ireland, it is suggested that policy makers and Local Authorities broaden their range of statistics, which they currently use to monitor tourism. Therefore, it is recommended that the ETIS to be rolled out nationwide and be supported by both the NTDA together with the EPA. Furthermore, this study is limited as it focuses only on one destination (Donegal) one possible avenue for future research may be to apply the ETIS in other destinations in Ireland, thus facilitating a future comparative study.

\section{References}

Alberti, F.G. and Giusti, J.D. (2012). Cultural Heritage, Tourism and Regional Competitiveness: The Motor Valley Cluster. City, Culture and Society, 3(4), $261-273$.
Amuquandoh, F. E. (2010). Residents' perceptions of the environmental impacts of tourism in the Lake Bosomtwe Basin, Ghana. Journal of Sustainable Tourism, 18, 223-238

Bauckham, W.K. (2005) Putting Traffic Lights on the Road Less Travelled: Ecotourism Certification and its Potential for Hawaii. Master of Arts. University of Hawaii Library

Bien, A. (2007) A Simple User's Guide to Certification for Sustainable Tourism and Ecotourism. Washington, DC: The International Ecotourism Society

Blackstock, K., McCrum, G., Scott, A and White, V. (Eds.). (2006). A Framework for Developing Indicators of Sustainable Tourism. CNPA and Macaulay Institute Sustainable Tourism Indicator Framework Project. Retrieved from http://www. macaulay.ac.uk/ruralsustainability/Framew orkReport.pdf (Accessed on 21.08.2016).

Blancas, F.J., Lozano, M., González, M., Guerrero, F.M., and Caballero, R. (2011). How to use sustainability indicators for tourism planning: The case of rural tourism in Andalusia (Spain). Scientific Total Environment. 412-413, 28-45.

Blancas, F.J., Lozano-Oyola, M and González, M (2015) A European Sustainable Tourism Labels Proposal using a Composite Indicator. Environmental Impact Assessment Review, 54, 39-54.

Buckley, P.J and Klemm, M.S (1993) The decline of tourism in Northern Ireland: The causes. Tourism Management, 14(3), 184-194

Buckley, R. (2011). Tourism and environment. Annual Review of Environment and Resources, 36, 397-416.

Conaghan, A. (2013) The Demand for and Supply of Sustainable Tourism in Ireland: Towards the Sustainable Management of Tourism Destinations. Ph.D. Research Thesis: (Institute of Technology, Sligo).

Connaught Ulster Waste Region (2015) Waste Management Plan 2015-2021. Available from http://www.sligococo.ie/Environment Waste/WasteManagement/ConnachtUlst erWasteManagementPlan2015-2021/ (Accessed on 15.09.2017).

Cooper, C. Fletcher, J. Fyall, A. Gilbert, D. and Wanhill, S. (2008) Tourism: Principles and 
McLoughlin, E., J. Hanrahan, A. Duddy, S. Duffy (2018) / European Journal of Tourism Research 20, pp. 78-91

Practice (4th). Harlow: Financial Times Prentice Hall.

Choi, H. and Sirakaya, E. (2006) Sustainability indicators for managing community tourism. Tourism Management, 27(6), 1274-1289.

Davenport, J and Davenport, J. L. (2006). The impact of tourism and personal leisure transport on coastal environments: A Review. Estuarine, Coastal and Shelf Science, 67, 280-292.

Denscombe, M. (2003) The Good Research Guide: For Small-scale Social Research (2nd). Buckingham: Open University Press

Dredge, D and Jenkins, J. (Eds.) (2011). Stories of Practice: Tourism Policy and Planning. Ashgate, Aldershot

Environmental Protection Agency [EPA] (2016) Urban Waste Water Treatment in 2015. Available from https://www.epa.ie/pubs/ reports/water/wastewater/2015\%20urban \%20waste\%20water\%20report_Web\%20 Version.pdf (Accessed on 10.09.2917).

European Commission [EC] (2013) JRC Scientific and Policy Reports: Best Environmental Management Practice in the Tourism Sector. Available from https://ec.europa.eu/jrc/en/publication/eurscientific-and-technical-research-reports /best-environmental-management-practice -tourism-sector (Accessed on 08.10.17).

European Commission [EC] (2016) European Tourism Indicator System for the Sustainable Management of Destinations. Available from http://ec.europa.eu/growth /sectors/tourism/offer/sustainable/indicator s/index_en.htm (Accessed on 27.06.17).

Fáilte Ireland (2013) Culture and Heritage Tourism: An Emerging Economic Engine. Press Releases 25th of April 2013. Available online http://www.failteireland.ie/ News-Features/News-Library/Culture-andheritage-tourism\%E2\%80\%A6an-emer ging-economic.aspx (Accessed on 11.04.15).

Fáilte Ireland (2016) Occupancy Survey 2016 : Dublin: Fáilte Ireland

Fáilte Ireland (2017) 'Overseas Visitors to Ireland January-September 2017'. Press Release $24^{\text {th }}$ of October 2017. Available from http://www.failteireland.ie/Utility/ News-Library/Overseas-Visitors-to-Ireland
-January\%E2\%80\%93September-201. aspx (Accessed on 09.12.2017).

Foh, L.K. (1999) Sustainable Tourism Destinations: Approaches and Methodology. International Institute for Industrial Environmental Economics, Lund University, Sweden

Geneletti, D and Dawa, D. (2009). Environmental impact assessment of mountain tourism in developing regions: $A$ study in Ladakh, Indian Himalaya. Environmental Impact Assessment Review, 29, 229-242.

Gössling, S., Peeters, P., Hall, C.M., Ceron, J.P., Dubois, G., Lehmann, L.V. and Scott, D (2012). Tourism and water use: Supply, demand, and security. Tourism Management, 33, 1-15

Gössling, S and Schumacher, K.P (2010). Implementing carbon neutral destination policies: Issues from the Seychelles. Journal of Sustainable Tourism, 18 (3), 377-391

Griffin, K., Morrissey, M. and Flanagan, S. (2010) Implementation of the DIT-ACHIEV Model for Sustainable Tourism Destination Management: Killarney, Ireland, A Case Study. Paper presented at the BEST Education Network Think Tank $X$ : Networking for Sustainable Tourism, Modul University, Vienna, Austria, 2010.

Griscom, H. P and Ashton, M. S. (2011). Restoration of dry tropical forests in Central America: A review of pattern and process. Forest Ecology and Management, 261, 1564-1579

Hanrahan, J and McLoughlin, E. (2015) A framework for analysing the Local Authorities tourism planning in Ireland: A socio-cultural perspective. European Journal of Tourism Research, 11, 73-86

Head, B.W. (2008) Three lenses of evidencebased policy. Australian Journal of Public Administration, 67(1), 1-11.

Hiltunen, M. J. (2007). Environmental impacts of rural second home tourism-case Lake District in Finland. Scandinavian Journal of Hospitality and Tourism, 7, 243-265.

Holden, A. (2008). Environment and Tourism. New York: Routledge.

Honey, M (2002) Ecotourism and Certification, Setting Standards in Practice. Washington DC: Island Press. 
Irish Examiner (2017) 'Donegal flood road repair will cost $€ 15.3 \mathrm{~m}$ ' Irish Examiner Article. September $11^{\text {th }}, 2017$. Available from http://www.irishexaminer.com/ breakingnews/ireland/donegal-flood-roadrepair-will-cost-153m-805528.html (Accessed on 30.10.2017).

Irish Tourist Assistance Service (2016) Annual Report. Available from http://itas.ie/wpcontent/uploads/2012/01/2016-Annual-

Report-Final-Version-PDF.pdf (Accessed on 17.09.2017).

Juvan, E and Dolnicar, S (2017) Drivers of proenvironmental tourist behaviours are not universal. Journal of Cleaner Production, 166, 879-890

Lee, T.H and Hsieh, H.P (2016) Indicators of sustainable tourism: A case study from a Taiwan's wetland. Ecological Indicators, 67, 779-787

Li, G., Yang, X., Liu, Q and Zheng, F (2014) Destination island effects: A theoretical framework for the environmental impact assessment of human tourism activities. Tourism Management Perspectives, 10, 11-18

Liu, A and Pratt, S (2017) Tourism's vulnerability and resilience to terrorism. Tourism Management, 60, 404-417

Lozano-Oyola, M., Blancas, F.J., González, M. and Caballero, R. (2012) Sustainable tourism indicators as planning tools in cultural destinations. Ecological Indicators, 18, 659-675.

Mason, P (2016) Tourism Impacts, Planning and Management (3rd). Routledge.

McLoughlin (2017) A Longitudinal Study on Local Authority Sustainable Planning for Tourism in Ireland: A Focus on Tourism Indicator Systems. PhD Research Thesis (Institute of Technology, Sligo)

McLoughlin, E and Hanrahan, J. (2017) Measuring the Economic Impact of Brexit through Evidence Based Planning for Tourism. In Hanrahan. J (eds.) (2017). Tourism and Hospitality Research in Ireland: Entrepreneurs Driving Tourism and Hospitality. Sligo: School of Business and Social Science, 29-41.

McLoughlin, E., and Hanrahan, J. (2016). Local authority tourism planning in Ireland: An environmental perspective. Journal of
Policy Research in Tourism, Leisure and Events, 8(1), 33-52.

Melia, P (2018) 'Exceptionally dry' April leads to water warnings'. Irish Independent Article, May $20^{\text {th }}, 2018$. Available from https://www.independent.ie/irish-news/ exceptionally-dry-april-leads-to-waterwarnings-35698854.html (Accessed on 20.05.2018)

Miller, G., Simpson, M. and Twinning-Ward, L. (2012) Study on the Feasibility of a European Tourism Indicator System for Sustainable Management at Destination Level. University of Surrey (U.K) Available from https://www.surrey.ac.uk/shtm/Files /Task\%201c)\%20Final\%20Case\%20Stud y\%20Review.pdf. (Accessed on 23.06.2014).

Mowforth, M., and Munt, I. (2016) Tourism and Sustainability: Development and New Tourism in the Third World. (4th) London: Routledge.

Needham, M.D and Szuster, B.W. (2011). Situational influences on normative evaluations of coastal tourism and recreation management strategies in Hawai. Tourism Management, 32 (4), 732-740.

Nickerson, N.P., Jake Jorgenson, J and Boley, B.B (2016) Are sustainable tourists a higher spending market? Tourism Management, 54, 170-177.

Pérez, V., Guerrero, F., González., Pérez. F and Caballero, R (2013) Composite Indicator for the Assessment of Sustainability: The Case of Cuban Naturebased Tourism Destinations. Ecological Indicators, 29, 316-324.

Pulina, M., Meleddu, M and Del Chiappa, G (2016) Residents' choice probability and tourism development. Tourism Management Perspectives 5, 57-67.

Ramos, V., Rey-Maquieira, J and Tugores, M. (2002). Empirical analysis of discrimination based on gender in an economy specialized in tourism. Annals of Tourism Research, 4(1), 239-258.

Rio D., and Nunes, L.M. (2012). Monitoring and evaluation tools for tourism destinations. Tourism Management Perspectives, 4, 6466

Roberts, S. and Tribe, J. (2008) Sustainability indicators for small tourism enterprises - 
An exploratory perspective. Journal of Sustainable Tourism, 16 (5), 575-594.

Sarantakos, S. (2005). Social research (2nd). South Melbourne: Palgrave MacMillan

Sasaki, M. (2004). Creativity and Cities: The Role of Culture in Urban Regeneration. Quarterly Journal of Economic Research, 27(3), 29-35.

Sustainable Energy Authority Ireland [SEAI] (2016) 'Renewable Electricity in Ireland 2015 http://www.seai.ie/resources/ publications/Renewable-Electricity-inIreland-2015.pdf (Accessed on 05.10.18).

Taplin, R.H (2013) The influence of competition on visitor satisfaction and loyalty. Tourism Management, 36, 238-246

Torres-Delgado, A. and Palomeque, F.L. (2014) Measuring sustainable tourism at the municipal level. Annals of Tourism Research, 49, 122-137.

Tourism Ireland (2017) http://www.ireland.com /accommodation/articles/accessibility/

UNEP-UNWTO. (2005). Making tourism more sustainable: A guide for policy-makers. Madrid: UNEP/UNWTO.

United Nations World Tourism Organisation [UNWTO] (2004) Indicators of Sustainable Development for Tourism Destinations: A Guidebook. Madrid: UNWTO
United Nations World Tourism Organisation [UNWTO] (2015) Tourism and the Sustainable Development Goals. Madrid: UNWTO

United Nations World Tourism Organisation [UNWTO] (2017) 'Average hotel energy consumption per guest night by region in 2007 (in mega joules)'. Available from https://www.statista.com/statistics/195728/ average-energy-consumption-per-guestnight-in-hotels-by-continent/ (Accessed on 12.10.2017)

Vila, T.D., Darcy, S and González, E.A (2015) Competing for the disability tourism market - A comparative exploration of the factors of accessible tourism competitiveness in Spain and Australia. Tourism Management, 47, 261-272

World Data Info (2017) Energy consumption in Ireland. URL: https://www.worlddata.info/ europe/ireland/energy-consumption.php (Accessed on 17.08.2017

World Tourism Organisation [WTO] (1996) What Tourism Managers need to know: $A$ Practical Guide to the Development and Use of Indicators of Sustainable Tourism. Madrid, WTO.

Xu, S., Barbieri, C., Anderson, D., Leung, Y.F and Rozier-Rich, S (2016) Residents' perceptions of wine tourism development. Tourism Management 55, 276-286. 